foul and smells badly, and at 6.4 we have the conditions produced by seaweeds rotting in a jar of water. From the change in $p \mathrm{H}$-values the quantity of carbon removed from solution in the sea in the form of carbon dioxide, and built up, by photosynthesis, into the tissues of marine plants, can be calculated. Represented as a hexose, the author gets the surprisingly great production of 250,000 kilograms produced per square kilometre of sea, in the English Channel between July and December. From similar observations made at Port Erin, Moore found a production of 300,000 kilograms per square kilometre during the six months that included the vernal maximum of diatom reproduction.

The other researches are equally important, especially as they deal with methods. The practice of determining organic matter by oxygen consumed in water samples is criticised. The reaction of the sap in the cells of marine algæ has been studied: it is shown to be almost neutral, in contrast with the acid sap of most land plants. Methods of finding the $\mathrm{H}$-ion concentration is. living algal cells are developed, and the influence of changes in $p \mathrm{H}$ is shown to be a factor in the distribution of shore weeds. Finally - a most useful result-the preparation of permanently acidfree formalin solutions is described. This series of papers by Dr. Atkins has particular interest for marine biologists.

J. J.

\section{The Structure of Coke.}

SIR GEORGE BEILBY has contributed an $S$ interesting paper entitled "The Structure of Coke, its Origin and Development," to the Transactions of the Society of Chemical Industry (November i5, I922). The paper contains a critical discussion of the changes that have been observed in coal and similar substances during the process of carbonisation, and an account of experimental work carried out on the micro-structure of coke and charcoal.

Use has been made of the new knowledge concerning solids and their internal constitution, for which Sir William Bragg is so largely responsible; and, in another direction, of the technique for cutting and studying sections of coal, introduced by $\mathrm{Mr}$. Lomax. A number of specimens for examination were photographed at their natural size, and with different magnifications and illuminations. It was observed how very much the structure of coke was determined by the size of the bubbles blown in the viscous mass during the semi-liquid stages of carbonisation, and even what have hitherto been commonly regarded as the solid vitreous cell-walls of the pores have been shown to be permeated by minute bubbles. Bound up with this is the control of the bubble formation which can be effected by blending coals of different behaviour, and the practical possibilities forthcoming in this way are discussed at some length. It is shown, for example, that the blending of a coal which swells and froths inordinately with another coal of the non-caking variety may be utilised for securing a strong and firm coke with small and evenly distributed pores.

The relevance of work by Messrs. Sutcliffe and Evans on the briquetting of pulverised coals as a preliminary to carbonisation is indicated. It has been claimed by them that the control of structure could be extended almost indefinitely by the briquetting of finely ground coal by pressure as a preliminary to carbonisation. It was by working along such lines that Sutcliffe and Evans were able to produce a material stated to have at least three times the gas-absorbing capacity of the best wood charcoal, and specially suitable for use in gas masks. Sir George Beilby points out that the combustion of these close-grained "pressure" briquettes proceeds definitely from the outer surfaces inwards, showing that the internal circulation of the oxidising gases is much more restricted than in the case of metallurgical coke - which raises an interesting question.

Seventeen figures are used to elucidate the argument of the text. They are all photo-micrographs of coke produced commercially in gas retorts, coke ovens, etc., or in the laboratory under special and controlled conditions.

J. W. C.

\section{University and Educational Intelligence.}

ABERDEEN. - The Thomson Lecturer for 1923 at the Aberdeen United Free Church College is Prof. J. Arthur Thomson, LL.D., whose subject is " What is Man? The Nature of Man Scientifically Considered."

Edinburgh.-Mr. G. G. Chisholm, reader in geography, is to retire at the end of September next, in consequence of which the University Court will shortly proceed to appoint a lecturer who will be responsible for, and in charge of, the teaching of geography in the University. The status of reader may be attached to the office. Applications for the post must reach the Secretary by, at latest, February 28 .

The late Mr. C. T. Milburn, of Newcastle-on-Tyne, bequeathed the sum of $10,000 l$. (in addition to $20,000 l$. given in his lifetime) to Armstrong College, expressing a wish that the legacy should be used for the endowment of a chair for the education of mining engineers or of naval architerts, and that his name should be associated with it.

THE annual prize distribution at the Sir John Cass Technical Institute, Aldgate, E.C.3, will be held on Wednesday, January 3I, when Sir Thomas Holland, after making the presentations, will deliver an address on "Humanism in Technical Education."

Messrs. Norton and Gregory, Ltd., offer two engineering scholarships to be competed for annually, one of value Iool. per annum, and one of value $50 l$. per annum, tenable for three years at any university in the United Kingdom or British Dominions. The honorary committee which will award the scholarships consists of Sir Joseph Petavel (Chairman), Prof. C. E. Inglis (Vice-Chairman), Prof. E. G. Coker, Mr. J. Talbot, Mr. G. H. Burkhardt, and the Chairman and Managing Director of Messrs. Norton and Gregory, Ltd. Candidates must have reached the age of it but not the age of 19 on March $I$ in the year of examination, be domiciled in the United Kingdom, and undertake to pursue a three years' course in engineering with the view of following it as a profession. Papers, which will cover two days' examination, will be set in English, mathematics, mechanics, and general physics. The main object of the examination will be to prove that candidates have received a good general education on broad lines and not necessarily specialised in engineering. The examination for the r923 scholarships will be held in March at a date to be fixed later, and all application forms must reach the committee not later than February 5. Official application forms may be obtained from the Secretary, Scholarships Committee, Messrs. Norton and Gregory, Ltd., I and 2 Castle Lane, Westminster, London, S.W.I. 